TI 2011-109/3

Tinbergen Institute Discussion Paper

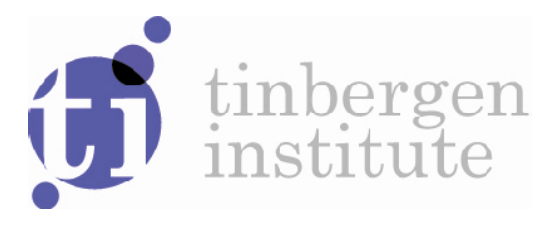

\title{
Importance of E-Services for Cultural Tourism
}

Eveline van Leeuwen

Peter Nijkamp*

Dept. of Spatial Economics, Faculty of Economics and Business Administration, VU University Amsterdam.

* Tinbergen Institute 
Tinbergen Institute is the graduate school and research institute in economics of Erasmus University Rotterdam, the University of Amsterdam and VU University Amsterdam.

More TI discussion papers can be downloaded at http://www.tinbergen.nl

Tinbergen Institute has two locations:

Tinbergen Institute Amsterdam

Gustav Mahlerplein 117

1082 MS Amsterdam

The Netherlands

Tel.: +31(0)205251600

Tinbergen Institute Rotterdam

Burg. Oudlaan 50

3062 PA Rotterdam

The Netherlands

Tel.: +31(0)10 4088900

Fax: $+31(0) 104089031$

Duisenberg school of finance is a collaboration of the Dutch financial sector and universities, with the ambition to support innovative research and offer top quality academic education in core areas of finance.

DSF research papers can be downloaded at: http://www.dsf.nl/

Duisenberg school of finance

Gustav Mahlerplein 117

1082 MS Amsterdam

The Netherlands

Tel.: +31(0)20 5258579 


\title{
Importance of E-services for Cultural Tourism
}

\author{
Eveline van Leeuwen and Peter Nijkamp \\ Department of Spatial Economics \\ VU University Amsterdam \\ De Boelelaan 1005, 1081HV Amsterdam \\ e.s.van.leeuwen@vu.nl_p.nijkamp@vu.nl
}

\begin{abstract}
Despite a busy lifestyle - or perhaps as a result of a stressful lifestyle - more people than ever before make leisure trips, sometimes for a long time but in many cases just for short periods. Modern telecommunication technology brings attractive tourist destinations directly into the living rooms of potential travellers, also destinations that would otherwise have been difficult to find, such as certain cultural heritage objects. In this contribution, we will address the relevance of e-services in urban cultural tourism. Its aim is to map out the relative drivers of cultural visitors to cities with a particular view on the importance of modern e-services in the tourist sector. We focus on three case-study cities: Amsterdam, Leipzig and Genoa. We use discrete choice models and factor analysis to analyse the preferences of tourists for cultural heritage and e-services. Interestingly, in all three cities, the most important group of tourists, the cultural heritage enthusiasts, are often international tourists. This stresses the importance of multilingual e-services in order to maximise their impact on cultural heritage visitors and the tourism sector in general. In addition, it is also important to note that certain e-services become more important for tourists from further away, such as online booking systems.
\end{abstract}

Keywords: Tourism, cultural heritage, e-services, ordered logit models, factor analysis. 


\section{People on the Move}

Tourism has evolved into a modern global-economic sector with a rapid growth pace in the past decades. According to the World Tourism Organization, in 2020, more than 720 million cross-border tourists will spend their holidays in Europe alone. Thus, the contribution of tourism to economic value creation and foreign trade is significant. With an average growth rate of approximately 5 percent over de past decades, tourism has turned into a major constituent of economic development world-wide, in both developed and developing countries.

Clearly, tourism is a complex phenomenon that generates various positive and negative socio-economic and ecological impacts. This has also prompted the need for sustainable tourism (see also Wall and Mathieson, 2006). The rapid rise in tourism has been driven by various socio-economic and cultural-ecological factors (see e.g. Fusco Girard and Nijkamp, 2009). In addition, it has also been stimulated or facilitated by a variety of background factors, in particular the enhanced transportation infrastructure; the increase in high-quality visitors' services in many places; and the broad package of facilities (e.g. natural resorts, cultural heritage, wildlife, arts or local atmosphere) in many places on earth. Furthermore, the tourist market has turned into a professional, modern and high-tech sector, where tour operators, hotel chains, tourist organizations and cities play a crucial role, increasingly so at a global level.

Tourism has also an important social and technological condition (see Giaoutzi and Nijkamp, 2006). Tourist-visits used to be a rather exceptional activity in the past, which could at best be afforded only once a year during the holiday season. At present, we observe the emergence of the age of mass tourism. Despite a busy lifestyle - or perhaps as a result of a stressful lifestyle - more people than ever before make leisure trips, sometimes for a long period but in many cases just for a short time. Geographical mobility is to a great extent accounted for by holiday seekers (in many cases even for short weekend trips).

Modern mass tourism will inevitably lead to increased competition among tourist destinations, as each tourist region seeks to attract a maximum share of the total stock of tourists. Consequently, tourism has become a key factor in regional development policy. A main challenge of modern regional policy is to market - often through the use of information and communication technologies (ICT) - the attractiveness of a certain region, so as to generate growth in tourist visits - and expenditures. Thus, ICT has become one of the competitive tools in regional tourist policy (see Goeldner and Ritchie, 2006). In the eyes of many decision makers and politicians, modern tourism has a magic potential. It generates external income and is based on the indigenous resources of the tourist areas concerned. Tourism has indeed become a rapidly growing sector and a wide-sweeping socio-economic phenomenon with broad economic, social, cultural and environmental consequences. Over the past 40 years, tourism has become a major activity in our society and an increasingly important sector in terms of economic development. It forms an increasing share of discretionary income and often provides new opportunities for upgrading the local environment. It is likely that tourism will continue to dominate the international scene of travel and leisure for many years to come. Tourism is therefore increasingly regarded as one of the development vehicles of a region, while it is an important growth sector in a country's economy. In both the industrialized and developing world, tourism is often seen as a source of revenues, as a potential for rapid growth, and as an environmentally-benign activity supporting sustainable development (see also Mathias et al., 2007) 
Finally, it should be noted that modern telecommunication technology brings attractive tourist destinations directly into the living rooms of potential travellers. This means that rising welfare and modern ICT may be held responsible for the global drive towards mass tourism. At the same time, a drastic restructuring of the tourist industry itself has taken place. First, a concentration in the sector has occurred; witness the emergence of large-scale international hotel chains. Secondly, as a result of these economies of scale, a further rationalization has taken place, where electronic booking and advanced pay systems have taken over much of the traditional 'handicraft' character of the hospitality business. But more importantly, the organization of tourism has come into the hands of a few large-scale tour operators who dominate a significant part of the international market. These operators form a critical intermediate segment between demand and supply, in that they do not only organize packages of trips for the traveller, but also increasingly dominate the hotel accommodation market, as well as the tourist transport market. By a keen combination of various opportunities and by using modern ICT as a spearhead, they are in a position to control large parts of the travel agency market and the transport market for tourists (see, e.g., Boniface and Cooper, 2001).

Against the above sketched background, we will address in the present paper the relevance of e-services in urban cultural tourism and its usefulness in attracting new visitors. The aim is to map out the different drivers of visitors of cultural heritage in cities together with their preferences for modern e-services. The paper is organised as follows. In the Section 2 we will offer a brief account of cultural heritage as a prominent tourist asset, whose social value for the visitor can be enhanced by an appropriate use of advanced e-services. Next, we will sketch out the research framework in Section 4, and present a data-base and modelling approach to the analysis of e-services in the tourism sector in three cities in Europe (Amsterdam, Leipzig and Genoa). We will in particular use ordered logit models together with factor analysis. This will be followed up by an interpretation of our empirical results by indicating target groups of tourists for each city in Section 5, while the paper will be concluded with retrospective and prospective remarks.

\section{Cultural Heritage as a Tourist Asset of Cities}

Many cities all over the world offer a wealth of cultural amenities, which are of great historical, architectural, artistic or political importance. Cultural heritage is not just a petrified resource from the past, but plays an active role in a modern open space-economy. In today's turbulent and competitive business world, modern cities and regions, as well as corporate organizations, are challenged to constantly innovate and improve the quality of their products and services in order to stay ahead of the fierce competition. In this fierce competition, the combined pressures of economic liberalization, increased globalization, technological change and shifts in regulatory systems lead to a complex local-global action space (the 'New Economy'). The world of business environments in modern economies and cities has changed the strategies of promoting cities and pursuing business dramatically (Spence, 2004), and depends nowadays heavily on the performance in generating, combining and utilizing new knowledge, imagination, creativity, innovations and technologies (Forte et al., 2006). Besides, our globalizing world has induced a high degree of geographical mobility, be it temporary (e.g. tourism) or permanent (e.g. immigration). Tourism in our modern world has many appearances, but a significant part of tourism is due to the attractiveness of cultural capital (e.g., cultural heritage) in cities. This has become a prominent economic asset in modern tourism.

Tourism is highly dependent upon the availability of cultural attractions for its development. An important contribution of cultural heritage lies in the support of the 
destination image generation. This means that cultural heritage is not only a source of historical information, affecting the image of the attraction itself, but also the broader destination image. Consequently, information provided to (potential) visitors has an impact on the destination image. Each destination offers a variety of products and services to attract visitors and each tourist has an opportunity to choose from a set of destinations (Crompton, 1992). Different factors may have an influence on destination choice. The tourism literature emphasizes the importance of both push and pulls factors in shaping tourist motivations and in choosing vacation destinations (Crompton, 1979). 'Push' factors are origin-related and refer to the intangible, intrinsic desires of the individual traveller, e.g. the desire for escape, rest and relaxation, adventure, health or prestige. 'Pull' factors are mainly related to the attractiveness of a given destination and tangible characteristics such as beaches, accommodation and recreation facilities and cultural and historical resources (Uysal and Hagan, 1993). Of course, the successfulness of these pull factors depends on the personal preferences of individual tourists.

\section{The Tourists' Choice}

Personal preferences, like motivations, may be both intrinsic, reflecting individual likes and dislikes, and extrinsic, or socially conditioned. Pearce (1988) stated that preferences are more specific than motivations, and are revealed by where travellers go and what travellers do. When tourists visit a destination, they stay at a hotel, often eat somewhere outside the hotel, shop, communicate with local people or employees and other colleagues and visit natural, cultural or historical places. All these elements contribute to the overall experiences of the tourists (Kozak, 2002).

There have been several studies on the preferences of travellers; these studies often used conjoint analysis (a stated preference method) that has been successfully applied in tourism as a technique to describe and forecast tourist choice behaviour (Suh and McAvoy, 2005, Riganti and Nijkamp, 2008). Important factors that influence people's choice of destination are: age, income, gender, personality, education, cost, distance, nationality, risk, and motivation, etc. (Hsu et al., 2009). In addition, also information sources and previous experiences affect the destination choice of visitors.

According to Ark and Richards (2006) culture has arguably become a major driving force of the urban tourism system. Cultural tourism is seen as being a major growth market in global tourism. Market trends, such as an ageing population and a growing interest in culture, seem to favour the development of cultural aspects of the urban tourism product (European Travel Commission 2004). Cities are, therefore, competing fiercely with each other to develop cultural attractions that will act as a 'must see sight' for cultural tourists. In addition, as visitors become better educated and more informed about tourist destinations, it opens new choices and provides new opportunities for unique experiences (Mohsin, 2005).

The research of Ark and Richards (2006) indicates that a high proportion of city visitors with cultural motivations come from neighbouring countries (European Travel Commission, 2004). A reason for this is that they are usually familiar with the specific kind of cultural values. In terms of destination attractiveness however, the more attractive destinations tend to be those that are further away, suggesting a certain element of 'exoticism' in the attractiveness of these places. It also appears that people who travel frequently and who are attracted to almost all cultural facilities they visit, often have a high level of cultural capital, developed both through stimulation of cultural consumption in the family and high levels of current cultural participation. They are also more likely to know the languages of the cities 
they visit than other respondents, so the 'living culture' of the destination is more accessible to them (Ark and Richards 2006).

Furthermore, it is important to stress that the selection of a certain vacation destination type implies a desire for some kind of benefit. Because of this, motivations play a fundamental role in destination choice, as they constitute internal thoughts which lead tourist behaviour towards certain ends (Nahab, 1975); in other words, they are the reasons why people take a vacation. We may consider four motivations: (1) The search for 'amusement', (2) tourist interest in 'broadening culture', (3) tourist interest in 'discovering new places', and (4) search for 'tranquillity'. The measurement of motivations is not simple, as it involves analyzing internal aspects of the individual that are not directly observable by the analyst (Nicolau and Mas, 2008).

In this behavioural context, Eyman and Ronning (1997) analyzed the effect of age and income on tourist behaviour and they found that the young travel less often but when they go they often choose the more cost-intensive vacation activities at more distant destinations with typically hot and sunny climates. Retired persons with high income were both more inclined to travel and to spend more expensive vacations. Furthermore, they found that parents prove to be less inclined to travel. Persons accompanied by children in the travel group, seem to prefer to spend vacations either with relatives (who might share the responsibility for the children) or to spend inactive vacations at traditional resorts within a small distance from home. Lawson (1991) found that stages in the family life cycle are reflected in the types of vacation taken and the financial expenditure outlaid. Social orientations of young singles were evident, as were constraints imposed by children. Vacation activities correlate with the age of adult members of the group. And finally, Eyman and Ronning (1997) found that respondents living in less urbanized areas seem to be more willing to travel and have a higher propensity to spend in their holidays.

Important insights from this literature review are that cultural heritage will increasingly become a toll to positively affect the destination image of a city. This is partly because of the growing competition in the tourism industry and the importance for a city to distinguish itself. At the same time, as the tourist population tends to become older, there will be a growing number of cultural heritage interested visitors. In order to spread tourists more equally over a city, ICT or e-services can be a useful tool to attract them to other, less wellknown, interesting (cultural heritage) sights.

\section{Preferences of Tourists for Cultural Heritage and E-services}

\subsection{Research Framework}

In this contribution, our aim is to address the relevance of e-services in urban cultural tourism and its usefulness in attracting new visitors. We want to map out the different drivers of visitors of cultural heritage in cities together with their preferences for modern e-services.

In line with the above described literature, we will look at the factors that affect a tourist's appreciation for cultural heritage. Apart from age, the literature suggests that there are many more factors that affect the appreciation for cultural heritage, such as the personal motivation for going on holiday or the country of residence. However, our main contribution will be that we will link the level of cultural heritage appreciation to the appreciation for different types of e-services, such as virtual tours, journey planners or online booking systems. As e-services can be a way to inform tourists about (less well-known) culturalheritage objects, we will analyse what kind of ICT tools would be most successful to attract new visitors. To find out which personal characteristics affect the appreciation of cultural heritage, as well as of e-services, we will use an ordered logit approach that can deal with the 1-5 scale. Secondly, we will perform a factor analytical approach to distinguish between 
different types of tourists based on their appreciation of cultural heritage, as well as of eservices. In this analysis we also take their motivation into account. The insights from those approaches will used to define target groups of tourists for each of the three cities.

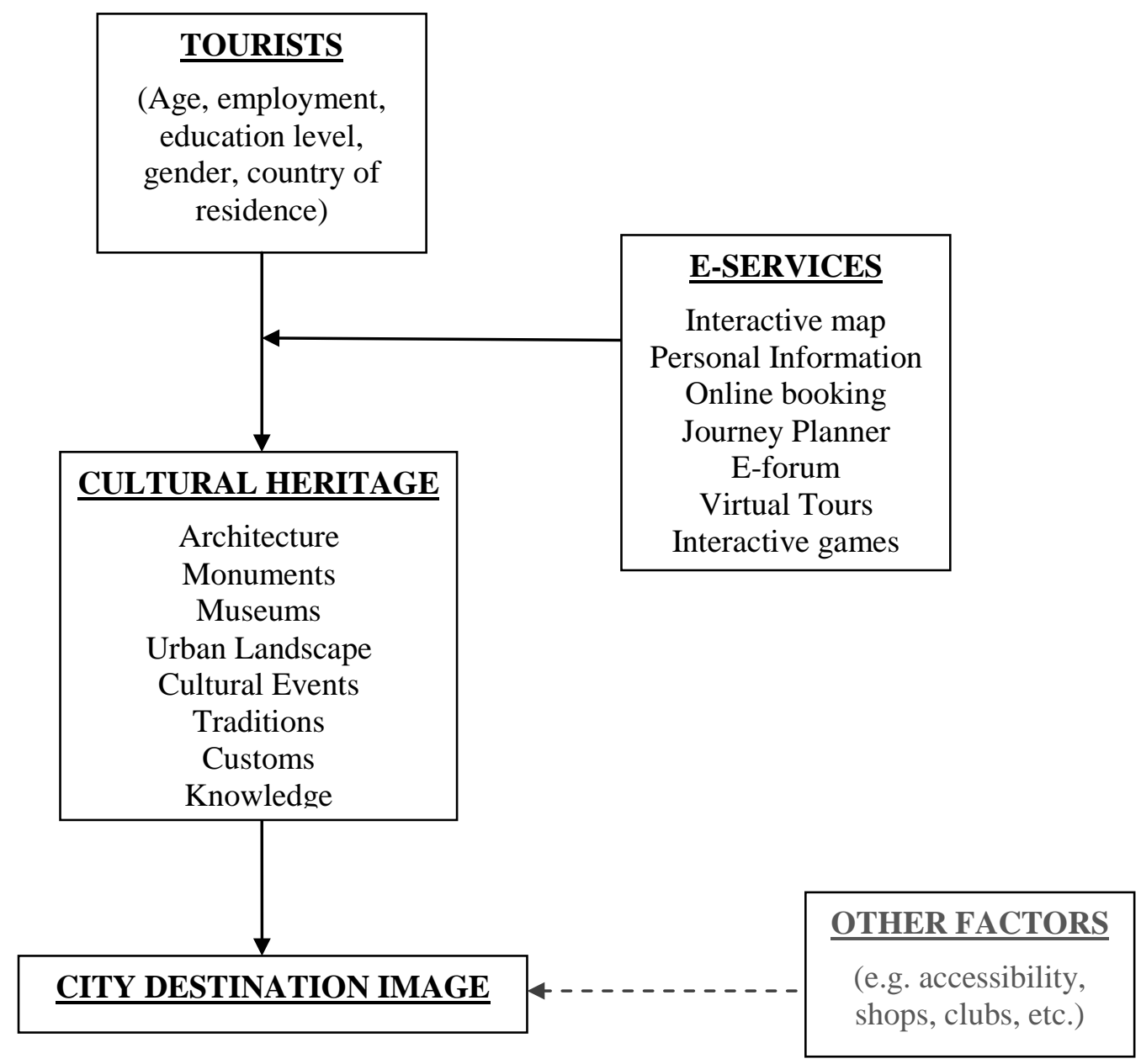

The data used for this contribution has been collected by user surveys carried out as part of the EU project ISAAC in the cities of Amsterdam, Leipzig and Genoa between August and November 2007 (see www.isaac-project.eu). These surveys involved extensive field data collection by interview teams hired and trained by the University of Nottingham. The questionnaires used both on-line and face-to-face interview modes (stand-alone computer versions or paper versions). In the survey, respondents were asked to value several cultural heritage characteristics) and e-services on scale of 1-5 (see Figure 1). Table 1 shows the number of respondents in each city, as well the share of them using e-services.

Table 1: Use of e-services by the interviewed persons

\begin{tabular}{l|cc}
\hline & $\mathrm{n}$ & \% using e -services \\
\hline Total & 1941 & 67 \\
\hline Amsterdam & 652 & 67 \\
Leipzig & 652 & 50 \\
Genoa & 637 & 83 \\
\hline
\end{tabular}

The respondents were also asked for their personal characteristics, for their motivation to visit one of the three cities and if they already planned something. It appears that there are 
considerable differences in what the plans of the tourists are. For example, Amsterdam is oftentimes visited because of the museums, atmosphere and nightlife. Tourists of Leipzig like to visit architecture, urban landscape and the atmosphere. Visitors of Genoa oftentimes plan to do business but also attend cultural events and architecture. Concerning the e-services also some major differences can be found in the use of e-services between visitors of the different cities. The tourists visiting Genoa are using far more e-services than tourists of Leipzig.

\subsection{Theoretical backgrounds of the ordered logit approach}

Within in the survey, respondents were asked to value several cultural heritage characteristics, as well as, e-services. Since these valuations of cultural heritage characteristics are captured into discrete, in contrast to continuous, dependent variables - ranging from not important to very important in five categories - standard regression tools are not applicable. Fortunately, several good alternatives are available to study how individual characteristics of respondents influence the valuation of cultural heritage and e-services. In this article, we will use an ordered choice approach. Ordered choice modelling is a method developed to handle discrete dependent variables as in our case.

The method of ordered choice modelling is an econometric tool frequently used in social sciences (see e.g. Greene and Hensher, 2008). As mentioned before, the linear probability model, using the ordinary least squares method (OLS), is not appropriate. Therefore, we use an ordered probability model. The ordered probability model is an extension of the binary probability model, whereby the dependent (qualitative) variable has a limited number of ordered outcomes. The standard example is of individuals choosing between four types of education: less than high school, high school, college, advanced degree. The order in the discrete outcomes is very clear.

More formally, the ordered probability model with individual data can be written as follows:

$$
y_{i}^{*}=\beta_{1} X_{1}+\beta_{2} X_{2}+\ldots+\beta_{n} X_{n}+\varepsilon_{i}
$$

The dependent variable, $y_{i}^{*}$, is the so-called latent variable and it depends linearly on the explanatory variables $X_{i}$, with $\mathrm{i}=1$..n. The error terms $\varepsilon_{i}$ complete the model; these error terms are assumed to be independent and identically distributed random variables. The latent variable $y_{i}^{*}$ is measured using the observed values of $y_{i}$, for example the appreciation of museums from 5-1, and the following censoring mechanism:

$$
\begin{aligned}
y_{i} & =\text { "very important", if } y_{i}^{*}>\mu_{1}, \\
& =\text { "important", if } \mu_{1}>y_{i}^{*}>\mu_{2}, \\
& =\text { "indifferent", if } \mu_{2}>y_{i}^{*}>\mu_{3}, \\
& =\text { "not really important", if } \mu_{3}>y_{i}^{*}>\mu_{4}, \\
& =\text { "totally not important", if } \mu_{4}>y_{i}^{*} .
\end{aligned}
$$

The $\mu$ values, which can be interpreted as boundaries, are estimated within the model. In addition, we use maximum likelihood procedures to estimate the ordered logit model ${ }^{1}$.

\footnotetext{
${ }^{1}$ We estimated the models with EViews, using the White-Heteroskedasticity-Consistent Standard Errors and Covariance maximum likelihood procedure.
} 
4.3 Behavioural models of valuation of different kinds of cultural heritage

In this section, we will look more closely at the tourists and their preferences for different kinds of cultural heritage $(\mathrm{CH})$. The ordered logit models provide insight in the combinations of the characteristics of the tourists that affect their preferences. For each city, we analyse which personal characteristics correlate with the 8 different kinds of $\mathrm{CH}$. The tourist characteristics that we included as explanatory variables in the models are a dummy for the use of e-services (ES), age, income level, education level, a gender-dummy, and a dummy if someone is employed or not. Furthermore, we add country-of-origin dummies, to correct for country-specific characteristics.

In Appendix 1, detailed tables with the results for all eight kinds of $\mathrm{CH}$ in the three cities can be found. Table 2 shows a summary of these results.

\section{Amsterdam}

An important variable for the tourists visiting Amsterdam is the use of ES for planning leisure activities. Table 2 shows that tourists that make use of ES often have a higher preference for all kinds of $\mathrm{CH}$. The age variable has a significant and positive influence on the valuation of tangible $\mathrm{CH}$ such as architecture, monuments and the urban landscape and a negative influence on the intangible $\mathrm{CH}$ valuation of cultural, traditions, customs and knowledge. This means that the older a person, the more likely that he or she enjoys tangible forms of $\mathrm{CH}$, the younger, the more likely he or she appreciates in particular intangible forms. Education follows the same pattern. When looking at the gender variable it appears that women tend to value all kinds of $\mathrm{CH}$ higher than men do.

Furthermore, almost all country (of residence) dummies are significant for the cultural events, traditions, customs and knowledge models: being a non-Dutch visitor increases the chance that one values traditions, customs and knowledge models higher. However, Dutch tourists more often prefer cultural events.

\section{Leipzig}

For the Leipzig tourists, the use of ES has a less significant effect compared to the Amsterdam models. Only for the intangible $\mathrm{CH}$ aspects, a significant positive correlation can be found; persons that appreciate intangible forms of $\mathrm{CH}$ more often are ES users. Being employed diminishes the chance of a high valuation of architecture, museums and cultural events. This variable has not been included in the Amsterdam model because it did not improve the results. Apparently in Leipzig, being employed or not is more important. On the other hand, the gender variable has less effect; we only find that men seem to favour monuments more often and women cultural events.

The two geographical dummies do not make a significant statistical difference, except for urban landscape and cultural events. This means that there are no differences between German and non-German visitors of Leipzig with respect to their valuation of $\mathrm{CH}$ in general. This result is different from the results obtained in Amsterdam. A reason for this can be that in Amsterdam a larger percentage of foreign visitors has been interviewed.

\section{Genoa}

The overall performance of the models for Genoa is not very high, which is reflected in the low number of significant parameters in each model. The level of variation in the dependent, as well as in the independent variables is probably too low.

From the visitors' sample we can only conclude that gender has a significant effect in three out of the eight models - architecture, museums and customs. This effect shows that in general women do have a higher value for cultural amenities. 


\section{Summary}

Table 2 shows a summary of the results for tangible $\mathrm{CH}$ (architecture, monuments, museums and urban landscape) and for the intangible types of $\mathrm{CH}$ (cultural events, traditions, customs and knowledge). The number of '+' or '-' shows the number of models (of types of $\mathrm{CH}$ ) in which the specific variable shows either a positive or negative significant relationship.

It appears that, in general, tourists who use ES to plan their visit have a higher appreciation for $\mathrm{CH}$. In Amsterdam, the age variable has a significant and positive influence on the valuation of tangible $\mathrm{CH}$ and a negative influence on the intangible $\mathrm{CH}$ valuation of cultural events, traditions, customs and knowledge, as has education. However, these patterns are not so clear in the other two cities.

Both in Amsterdam and Leipzig, higher educated tourists value tangible $\mathrm{CH}$, while lower educated tourists often appreciate intangible $\mathrm{CH}$. Being employed is only an important variable in the case of Leipzig. Finally, in all three cities it appears that, in general, women seem to appreciate $\mathrm{CH}$ more.

For the country of residence variable, it is not possible to find a clear pattern. We can only say that Dutch tourists in Amsterdam appreciate, in particular, cultural events while tourists from other countries prefer other forms of intangible $\mathrm{CH}$. In Germany, also the German tourists value cultural events more than other tourists do. In Genoa, the Italian tourists seem to value the monuments in Genoa less than the other tourists do.

Table 2: Summary of the results of the ordered logit models estimating the preferences of tourists in the three cities for different kinds of $\mathrm{CH}$

\begin{tabular}{|c|c|c|c|c|c|c|}
\hline & \multicolumn{3}{|c|}{ Tangible CH } & \multicolumn{3}{|c|}{ Intangible $\mathrm{CH}$} \\
\hline & Amsterdam & Leipzig & Genoa & Amsterdam & Leipzig & Genoa \\
\hline E-service & +++ & & + & ++ & +++ & + \\
\hline Age & ++++ & + & & - - - & & \\
\hline Education & ++ & ++ & - & - . - & $+/-$ & \\
\hline Employed & & - & & & - & \\
\hline Gender & ++++ & - & ++ & +++ & + & + \\
\hline Income & & - & & & & \\
\hline Germany & $+/-$ & & & $-/+$ & & \\
\hline UK & & & & $-/+++$ & & \\
\hline USA & & & & $-/+++$ & & \\
\hline Italy & & & - & & & \\
\hline Rest Europe & + & & & $-/+++$ & - & \\
\hline Rest World & & - & & $-/+++$ & & \\
\hline
\end{tabular}

The number of '+' or '-' shows the number of models in which the specific variable shows either a positive or negative significant relationship.

\subsection{Behavioural models of valuation of different e-services}

The Internet plays an indispensable role in international and national tourism and will most likely become the critical tool for tourism in the future. This also leads to service competition among tourist facilities in areas of destination, where firms are increasingly involved in global competition (even when they belong to the SME sector) (van Leeuwen and Nijkamp 2009).

In this section, we describe the results of the ordered logit-models used to investigate which variables influence the appreciation of different ES. We differentiate between interactive maps, personalised information, booking service, journey planner, e-Forum, virtual 
tours and interactive games. The detailed tables can be found in Appendix 2. Table 3 shows a summary.

\section{Amsterdam}

Not very surprising, it appears that tourists that already use ES often have a higher appreciation for the different ES. Especially, the appreciation of a booking service increases with the use of ES. A reason for this relation can be that people who use ES already know that using them in planning and organizing a trip is useful. Furthermore, we observe that education has a mixed effect. In general, when the coefficient of this variable is significant, education has a negative impact on the appreciation of different ES. This variable is not significant for more or less 'traditional' ES such as an online booking system, journey planners or interactive maps. E-forums, virtual tours, personalized information and interactive games are more 'modern' and ‘trendy' forms of ES and are more appreciated by less educated tourists.

Gender only has a statistical impact on the appreciation of virtual tours and interactive games. It appears that men value these ES higher than women do. In addition, also younger tourists favour these kinds of ES more often. More generally, younger people tend to find ES more important than older people. Possible, older people do not know how to access certain ES. This is confirmed by the statistically significant coefficients of the appreciation of eforums and interactive games.

Concerning the country of residence, it appears that tourists from the USA or Canada value some ES (interactive map, personalized information and booking services respectively) higher than tourists from the Netherlands do. Perhaps these ES are more frequently used in the United States or Canada. Also, tourists from UK, Ireland and the rest of the world value ES in general more than tourists from the Netherlands do.

\section{Leipzig}

From the tourists visiting Leipzig, the users of ES appreciate ES more than people who do not use ES. An exception is the model for interactive games. Furthermore, the level of education and modern ES (e-forum, virtual tours, and interactive games) are negatively related. When someone has a higher degree he or she values e-forums, virtual tours and interactive games less. Thirdly, gender does not significantly influence the appreciation of any e-service, which is somewhat surprising. Taking the results of Amsterdam into consideration we expected that especially the appreciation of virtual tours and interactive games would be lower for women. Furthermore, it appears that the relation between age and the appreciation of interactive games is negative: when one gets older one value interactive games less. Finally, there are some country-specific differences in the valuation of ES. Tourists from Holland value ES less than German tourists do. Dutch tourists value booking services and journey planners significantly lower. This is in line with what we found in Amsterdam (that Dutch tourists tend to appreciate ES less than foreign visitors). Tourists from the rest of the world value ES higher, especially personalized information and booking systems. Possibly because they have to do more research before they plan their trip, while German tourists already know more about the cultural environment of Leipzig.

\section{Genoa}

For the tourists in Genoa it appears that when they use ES they appreciate a journey planner less. Furthermore, age has a significant negative effect on the appreciation of interactive games. Again we find that when getting older, one appreciates interactive games less. Finally, we observe that in some specific cases, tourists from other countries than Italy value ES differently than Italian tourists do (e.g. tourists from Spain appreciate personalized information more than Italian tourists; tourists from the rest of the world value booking services less than Italian tourists). 


\section{Summary}

Based on the analyses presented in the preceding paragraphs and summarised in Table 3 we can come to some more general conclusions.

First, we see that users of ES are valuing different ES often higher than people who are not yet familiar with ES. This is not surprising, given the fact that ES users are better able to value the usefulness of ES than non-users. However, this relationship does not exist for every kind of ES. Secondly, age appears to influence the appreciation of some forms of ES. Especially interactive games are more appreciated by young tourists. This is quite intuitive: we see that youngsters like to play computer games while elderly people are quite often not familiar with such forms of amusement. Also gender and interactive games are negatively related, although only in Amsterdam this coefficient is significant. This means that men like interactive games more than women. Furthermore, it appears that in Amsterdam and Leipzig, the education level significantly affects the experience with ES: lower educated tourists appreciate in particular the interactive ES more. In Genoa, this relationship seems to be the opposite, but here the positive relationship deals with more the traditional kind of ES, namely the journey planner.

Finally, the country-specific differences in the appreciation of ES do not show a general pattern. Again, these variables are most important for the Amsterdam case.

Table 3: Summary of the results of the ordered logit models estimating the preferences of tourists in the three cities for different kinds of ES

\begin{tabular}{l|ccc}
\hline & & E-services \\
\hline E-service & Amsterdam & Leipzig & Genoa \\
Age & +++++ & ++++++ & $-/+$ \\
Education & --- & - & - \\
Employed & --- & --- & ++ \\
Gender & + & & - \\
\hline Germany & -- & & + \\
Holland & - & -- & \\
UK & & - & \\
USA & +++++ & + & $-/+$ \\
Italy & +++ & & + \\
Spain & & & - \\
Rest Europe & $-/++++$ & + & \\
Rest World & ++++ & ++ & \\
\hline
\end{tabular}

The number of '+' or '-' shows the number of models in which the specific variable shows either a positive or negative significant relationship.

\subsection{Appreciation of cultural heritage}

Because the choice models are applied to estimate preferences of tourists for 8 different components of cultural heritage, and because a relatively large number of characteristics are used as independent variables, it is difficult to draw clear-cut conclusions, for example about future target groups. Therefore, we will use, in addition, a factor analytic approach. Factor analysis is a multivariate statistical approach that can be used to analyse interrelationships between a large number of variables, and to explain these variables in terms of their common 
underlying dimensions. The underlying assumption is that there exists a number of unobserved latent 'factors' that account for the correlations among observed variables. The main purpose of factor-analytic techniques is to reduce the number of mutually-correlated variables, and/or to detect underlying patterns or a structure in the relationships between variables. In our case, however, the aim is not in particular to condense the number of variables, but with a limited number of factors, it is easier to identify significant differences between groups of tourists. Here, we use specifically a principal component analysis with a varimax rotation. The factors extracted by this method are by definition uncorrelated and can be arranged in order of decreasing variance. To easily interpret the factors, we focus on components with a loading higher than 0.4 , although variables with a loading equal to, or greater than, 0.35 may still be meaningful in order to decrease the probability of misclassification (Hair et al., 1995).

Apart from the preferences for different types of cultural heritage, we also include what tourists planned to visit or to do (which can be interpreted as their motivation).

\section{Amsterdam}

The factor analysis that deals with the preferences and plans of tourists visiting Amsterdam extracts 5 components explaining 58 per cent of the variance (see Table 4). The first component can be interpreted as persons who like all kinds of $\mathrm{CH}$, in particular the intangible ones such as traditions, customs and knowledge. They also plan to visit one or more museums. The second component can be interpreted as tourists that are not interested in $\mathrm{CH}$, especially not in architecture and museums and so on; instead they come to enjoy the cities nightlife and atmosphere. The third component can be interpreted as tourists not interested in intangible $\mathrm{CH}$ but who planned to visit architecture, museums and the urban landscape. The fourth component deals with tourists specifically interested in cultural events and who planned to visit such an event. The final component can be interpreted as tourists who come to shop in Amsterdam.

Table 4: Factor analysis for tourists in Amsterdam with respect to cultural heritage

\begin{tabular}{l|ccccc}
\hline & \multicolumn{5}{|c}{ Factors } \\
& 1 & 2 & 3 & 4 & 5 \\
\hline Variance explained & $20 \%$ & $13 \%$ & $11 \%$ & $8 \%$ & $6 \%$ \\
\hline Preference & & & & & \\
\hline Architecture & $\mathbf{0 . 4 7 8}$ & $\mathbf{- 0 . 5 4 7}$ & 0.334 & -0.015 & 0.103 \\
Monuments & $\mathbf{0 . 4 5 9}$ & $\mathbf{- 0 . 5 2 0}$ & 0.202 & 0.148 & 0.194 \\
Museums & 0.390 & $\mathbf{- 0 . 4 6 2}$ & 0.292 & 0.286 & -0.025 \\
Urban Landscape & 0.397 & $\mathbf{- 0 . 5 0 5}$ & 0.194 & -0.099 & 0.031 \\
Cultural Events & 0.336 & -0.248 & $\mathbf{- 0 . 5 2 0}$ & $\mathbf{0 . 5 0 3}$ & -0.146 \\
Traditions & $\mathbf{0 . 7 0 8}$ & 0.118 & $\mathbf{- 0 . 4 1 9}$ & -0.230 & -0.005 \\
Customs & $\mathbf{0 . 7 3 0}$ & 0.058 & -0.380 & -0.294 & -0.015 \\
Knowledge & $\mathbf{0 . 6 8 7}$ & 0.015 & -0.374 & -0.289 & 0.046 \\
\hline Planning to visit & & & & & \\
\hline Architecture & $\mathbf{0 . 4 5 3}$ & 0.297 & $\mathbf{0 . 4 3 4}$ & 0.050 & -0.206 \\
Museums & 0.317 & 0.300 & $\mathbf{0 . 5 1 8}$ & 0.014 & 0.093 \\
Urban landscape & 0.378 & 0.265 & 0.452 & -0.223 & -0.262 \\
Cultural Events & 0.340 & 0.293 & -0.123 & $\mathbf{0 . 6 8 4}$ & -0.241 \\
Shopping & 0.160 & 0.337 & 0.057 & 0.177 & $\mathbf{0 . 7 9 9}$ \\
Nightlife & 0.306 & $\mathbf{0 . 4 7 4}$ & -0.046 & 0.167 & 0.284 \\
Atmosphere & 0.389 & $\mathbf{0 . 5 1 4}$ & 0.201 & 0.048 & -0.204 \\
\hline
\end{tabular}


Now that we have specified five different groups of tourists, we can use the factor loadings to see what the personal characteristics are related to these five groups. The factor loading is the Pearson correlation between a factor and a variable. Factor score coefficients can be calculated in several ways, the simplest way is the regression method. This means that the factor loadings are adjusted to take account of the initial correlations between variables.

It appears that the $\mathrm{CH}$ enthusiast is often a younger female, visiting Amsterdam on a holiday trip, who uses ES. In addition, it is less likely that she is Dutch or from Germany, and more likely that she is from the UK, rest of Europe or rest of the world.

The nightlife enjoyers are generally young males, with a lower education and lower income. They are in Amsterdam for holiday reasons and usually not a member of a $\mathrm{CH}$ association. Furthermore, they are generally not from the Netherlands, but from surrounding countries or from the USA. The tourists, in particular interested in tangible $\mathrm{CH}$ are often the older tourists, with a higher education. They do not come for business reasons but for pleasure. They often come from Germany or from the rest of Europe.

The cultural events fans are often younger male tourists, who are not in Amsterdam for holiday reasons (but probably to visit friends), who do use ES and generally come from the Netherlands. Finally, the shoppers: they can be typified as female tourists with a higher income, not a member of a $\mathrm{CH}$ association and most likely from the UK.

Leipzig

According to the factor analysis of the Leipzig tourists, 5 components can be distinguished (see Table 5). The first group of tourists can be typified as $\mathrm{CH}$ enthusiast, but without the clear intention to visit anything. The second component can be described as tourists that plan to visit tangible $\mathrm{CH}$ attractions and that don't prefer intangible $\mathrm{CH}$. Furthermore, they do not intend to visit the nightlife of Leipzig.

The third group of tourists consist of persons that like architecture and the urban landscape, what they plan to visit. However, they are not so much interested in museums or cultural events and do not intend to visit them.

The fourth component is characterized by tourists that are not particularly interested in $\mathrm{CH}$, but that like shopping and visiting the city's nightlife and enjoying the atmosphere. Finally, the fifth and smallest group of tourists are those that are particularly interested in the urban landscape and not so much in monuments.

Table 5: Factor analysis for tourists in Leipzig with respect to cultural heritage

\begin{tabular}{l|ccccc}
\hline & \multicolumn{5}{|c}{ Factors } \\
& 1 & 2 & 3 & 4 & 5 \\
\hline Variance explained & $20 \%$ & $13 \%$ & $11 \%$ & $8 \%$ & $6 \%$ \\
\hline Preference & & & & & \\
\hline Architecture & $\mathbf{0 . 6 4 3}$ & 0.377 & 0.350 & -0.014 & -0.093 \\
Monuments & $\mathbf{0 . 6 6 9}$ & 0.065 & 0.132 & -0.140 & $\mathbf{- 0 . 4 0 5}$ \\
Museums & $\mathbf{0 . 6 9 1}$ & 0.251 & -0.330 & 0.070 & -0.213 \\
Urban Landscape & $\mathbf{0 . 5 4 7}$ & 0.148 & 0.352 & 0.191 & 0.363 \\
Cultural Events & $\mathbf{0 . 6 1 5}$ & 0.123 & -0.353 & 0.145 & 0.158 \\
Traditions & $\mathbf{0 . 6 4 3}$ & $\mathbf{- 0 . 4 2 5}$ & -0.044 & -0.111 & 0.075 \\
Customs & $\mathbf{0 . 6 3 5}$ & $\mathbf{- 0 . 5 6 7}$ & 0.034 & -0.124 & 0.103 \\
Knowledge & $\mathbf{0 . 6 5 1}$ & $\mathbf{- 0 . 5 3 8}$ & -0.064 & -0.088 & 0.067 \\
\hline Planning to visit & & & & & \\
\hline Architecture & 0.222 & 0.318 & $\mathbf{0 . 5 0 1}$ & -0.020 & -0.253 \\
Museums & 0.297 & 0.357 & $\mathbf{- 0 . 4 7 9}$ & 0.188 & -0.266 \\
Urban landscape & 0.217 & 0.353 & 0.383 & 0.000 & $\mathbf{0 . 5 9 0}$
\end{tabular}




\begin{tabular}{l|ccccc} 
Cultural Events & 0.184 & 0.348 & $\mathbf{- 0 . 5 1 2}$ & 0.284 & 0.297 \\
Shopping & -0.074 & -0.241 & -0.004 & $\mathbf{0 . 6 3 8}$ & 0.095 \\
Nightlife & -0.074 & $\mathbf{- 0 . 4 4 6}$ & 0.099 & $\mathbf{0 . 4 8 6}$ & -0.119 \\
Atmosphere & 0.088 & -0.007 & $\mathbf{0 . 4 1 5}$ & $\mathbf{0 . 5 4 1}$ & -0.277
\end{tabular}

When looking at the personal characteristics of the five groups of Leipzig tourists, it appears first of all that the $\mathrm{CH}$ fans are generally older women with a higher education. They visit Leipzig for pleasure and they use ES to prepare for their leisure time. Furthermore, they are often not from Germany.

The tourists that favour tangible $\mathrm{CH}$ are also often older and higher educated persons, with higher income, but not necessarily women. They are often from Holland and less often from Germany.

The third group of tourists, that in are in particular interested in architecture, and not in intangible $\mathrm{CH}$, often have a higher income, they do not use ES and they are generally not a member of a $\mathrm{CH}$ association. They are mostly German.

Not surprisingly, the shopping and nightlife tourist are often younger persons, women with a lower education. They visit Leipzig during their holidays, and not for business reasons. They are mostly Germans as well, not from the USA or from the rest of the world. Also the urban landscape fans are generally women, this time with a lower education. They do use ES and are from Germany as well.

\section{Genoa}

As we saw in the section describing the ordered logit models, also now it appears that the results for Genoa are less rich compared to Leipzig and Amsterdam. However the factor analysis does show interesting groups of tourists.

The five factors or groups of tourists that can be distinguished are quite clear (see Table 6). First of all, the general $\mathrm{CH}$ fans can be distinguished. Those tourists like all kinds of $\mathrm{CH}$, only they haven't made any plans yet to visit them. This factor explains 20 per cent of the variance.

The second group can be seen as those tourists that in particular favour tangible $\mathrm{CH}$. They have also planned to visit some of those places. The third factor can be explained as the group of tourists that do not really like tangible $\mathrm{CH}$, instead they prefer intangible $\mathrm{CH}$. The fourth group consist of persons that enjoy the city's nightlife and atmosphere and the final group likes to go shopping and visiting cultural events.

Table :6 Factor analysis of tourist preferences in Genoa with respect to cultural heritage

\begin{tabular}{l|ccccc}
\hline & \multicolumn{5}{|c}{ Factors } \\
& 1 & 2 & 3 & 4 & 5 \\
\hline Variance explained & $20 \%$ & $13 \%$ & $11 \%$ & $8 \%$ & $6 \%$ \\
\hline Preference & & & & & \\
\hline Architecture & 0.271 & $\mathbf{0 . 4 4 9}$ & $\mathbf{- 0 . 4 0 6}$ & -0.107 & 0.219 \\
Monuments & $\mathbf{0 . 4 1 4}$ & $\mathbf{0 . 4 2 8}$ & -0.376 & -0.082 & 0.132 \\
Museums & $\mathbf{0 . 4 6 8}$ & $\mathbf{0 . 4 7 1}$ & -0.275 & -0.027 & -0.007 \\
Urban Landscape & $\mathbf{0 . 4 3 5}$ & $\mathbf{0 . 4 1 3}$ & -0.135 & 0.118 & -0.008 \\
Cultural Events & $\mathbf{0 . 5 0 7}$ & 0.164 & -0.088 & 0.080 & -0.112 \\
Traditions & $\mathbf{0 . 5 6 2}$ & 0.083 & 0.387 & 0.057 & -0.059 \\
Customs & $\mathbf{0 . 5 6 1}$ & 0.003 & $\mathbf{0 . 5 5 6}$ & -0.197 & -0.106 \\
Knowledge & $\mathbf{0 . 4 8 3}$ & 0.093 & $\mathbf{0 . 6 1 1}$ & -0.025 & -0.069 \\
\hline Planning to visit & & & & & \\
\hline Architecture & $\mathbf{0 . 5 0 7}$ & $\mathbf{0 . 5 9 0}$ & 0.260 & -0.155 & 0.019
\end{tabular}




\begin{tabular}{l|ccccc} 
Museums & -0.357 & $\mathbf{0 . 6 5 4}$ & 0.170 & -0.180 & -0.007 \\
Urban landscape & $\mathbf{- 0 . 4 1 3}$ & $\mathbf{0 . 5 3 3}$ & 0.287 & -0.236 & 0.195 \\
Cultural Events & 0.123 & -0.203 & 0.050 & -0.094 & $\mathbf{0 . 7 2 3}$ \\
Shopping & 0.129 & -0.155 & 0.235 & 0.157 & $\mathbf{0 . 6 3 0}$ \\
Nightlife & -0.073 & 0.235 & -0.028 & $\mathbf{0 . 7 7 5}$ & 0.035 \\
Atmosphere & -0.193 & 0.312 & 0.280 & $\mathbf{0 . 6 1 1}$ & 0.024 \\
\hline
\end{tabular}

When we look at the correlation between personal characteristics and those five factors, unfortunately not many variables show a significant relationship. However, the $\mathrm{CH}$ fans are often men on business trips. This could explain why they haven't planned to visit anything. They use ES and are often member of a $\mathrm{CH}$ association. They are often from the rest of Europe. The tangible $\mathrm{CH}$ fans are often older persons, with a slightly lower education. They are in Genoa for holiday, not for business. The tourists that favour intangible $\mathrm{CH}$ are generally younger and they are on holiday. The ones that enjoy the nightlife of Genoa are often Spanish tourists. Finally, concerning the ones that go to Genoa for cultural events and shopping, we find that they do not visit Genoa for business reasons and they generally are not from Spain.

\subsection{Appreciation of E-services}

\section{Amsterdam}

After having looked at preferences for culture heritage, now we also apply factor analysis to the preferences of tourists for different e-services. When focussing on the Amsterdam tourists, two components can be extracted, which explain together 57 per cent of the variance. The first component consists of persons liking ES in general; the ES enthusiast. Interestingly, the second component includes tourists that like interactive games and that have no preference for online booking (see Table 7).

Table 7: Factor analysis of tourist preferences in Amsterdam with respect to e-services

\begin{tabular}{l|cc}
\hline & \multicolumn{2}{|c}{ Factors } \\
& 1 & 2 \\
\hline Variance explained & $42 \%$ & $15 \%$ \\
\hline Preference & & \\
\hline Interactive map & $\mathbf{0 . 6 3 3}$ & -0.254 \\
Personal information & $\mathbf{0 . 6 3 3}$ & -0.035 \\
Online booking & $\mathbf{0 . 6 9 3}$ & $\mathbf{- 0 . 5 2 4}$ \\
Journey planner & $\mathbf{0 . 6 1 3}$ & -0.316 \\
E-forum & $\mathbf{0 . 6 3 3}$ & 0.291 \\
Virtual tours & $\mathbf{0 . 7 1 3}$ & 0.207 \\
Interactive games & $\mathbf{0 . 7 2 3}$ & $\mathbf{0 . 6 7 9}$ \\
\hline
\end{tabular}

The personal characteristics of the tourists that can be labelled as ES enthusiasts are: younger tourists, males, with a lower education. They use ES and are interested in many kinds of $\mathrm{CH}$. There is a positive relation with tourists that visit Amsterdam for pleasure, from the UK or the rest of Europe. These kinds of tourists are less likely to come from the Netherlands or from Germany.

The tourist that are interested in online games and not in an online booking system are often younger tourists, male with a lower education and income. A strange result is that they do not use ES when planning their leisure time. That could explain why they are not interested 
in an online-booking system, but more in online games. They are not so much interested in tangible $\mathrm{CH}$, more in cultural events. They often come from Germany.

\section{Leipzig}

When looking at the appreciation of ES by visitors of Leipzig two components can be distinguished: ES enthusiasts and persons that favour interactive ES such as an e-forum and interactive games (see Table 8).

Table :8 Factor analysis of tourist preferences in Leipzig with respect to e-services

\begin{tabular}{l|cc}
\hline & \multicolumn{2}{|c}{ Factors } \\
& 1 & 2 \\
\hline Variance explained & $46 \%$ & $17 \%$ \\
\hline Preference & & \\
\hline Interactive map & $\mathbf{0 . 7 1 8}$ & -0.313 \\
Personal information & $\mathbf{0 . 7 6 1}$ & 0.124 \\
Online booking & $\mathbf{0 . 5 9 8}$ & $\mathbf{- 0 . 5 5 6}$ \\
Journey planner & $\mathbf{0 . 7 1 9}$ & -0.339 \\
E-forum & $\mathbf{0 . 6 9 5}$ & 0.449 \\
Virtual tours & $\mathbf{0 . 7 1 8}$ & 0.091 \\
Interactive games & $\mathbf{0 . 4 8 0}$ & $\mathbf{0 . 6 8 6}$ \\
\hline
\end{tabular}

The first group of tourists is used to ES and they often do not have a membership of a $\mathrm{CH}$ association. They are interested in all kinds of $\mathrm{CH}$ and are less often from the Netherlands and more often from the rest of the world. The tourists that favour interactive ES are often younger lower educated persons with a lower income. They do not use ES to organize their leisure time and they do not visit Leipzig for business reasons.

\section{Genoa}

When looking at the appreciation of ES in Genoa two factors can be distracted, explaining 44 per cent of the variance (see Table 9). The first factor could be identified as tourists that like more the conventional ES. The second as residents that like interactive games, virtual tours and e-forum.

Table :9 Factor analysis of tourist preferences in Genoa with respect to e-services

\begin{tabular}{l|cc}
\hline & \multicolumn{2}{|c}{ Components } \\
& 1 & 2 \\
\hline Variance explained & $26 \%$ & $18 \%$ \\
\hline Preference & & \\
\hline Interactive map & $\mathbf{0 . 6 0 9}$ & -0.112 \\
Personal information & $\mathbf{0 . 4 7 4}$ & -0.129 \\
Online booking & $\mathbf{0 . 7 5 6}$ & -0.219 \\
Journey planner & $\mathbf{0 . 7 3 0}$ & 0.003 \\
E-forum & 0.222 & $\mathbf{0 . 4 9 5}$ \\
Virtual tours & 0.145 & $\mathbf{0 . 6 2 8}$ \\
Interactive games & 0.123 & $\mathbf{0 . 7 4 2}$ \\
\hline
\end{tabular}

The tourists that prefer more so-called conventional ES are also tourists that favor intangible $\mathrm{CH}$. Unfortunately, not more variables are significantly related. The tourists liking 
interactive ES are often younger persons, persons with a lower education who are not so much interested in tangible $\mathrm{CH}$.

\section{Summary}

To summarise, it appears that a large group of the tourists that have been questioned are really $\mathrm{CH}$ enthusiasts; they are interested in all kinds of $\mathrm{CH}$. In almost all cities, the first and largest factor can be interpreted as $\mathrm{CH}$ fans. Interestingly, these groups are not (always) related to persons that also planned to visit a $\mathrm{CH}$ site. The second biggest factor that often shows up contains the tourists that favour tangible $\mathrm{CH}$. Furthermore, in all three cities a group of tourists can be distinguished that visits the city in particular for shopping reasons, as well as a group that enjoys the city's nightlife and atmosphere. In general this factor explains a smaller part of the variance (around 10 per cent), only in Amsterdam, enjoying the city's nightlife and atmosphere is the second biggest group.

Related to the ES it appears that the factors are more similar in the three cities than for $\mathrm{CH}$. In all cities, the largest variance can be explained by tourists that like all kinds of ES. Furthermore, we can distinguish persons that prefer more conventional ES and persons that like the interactive ES such as interactive games and e-forums. Interestingly, both in Leipzig and Amsterdam, the persons that prefer interactive ES are not interested in an online-booking system.

\section{Target Groups for Amsterdam, Leipzig and Genoa}

\subsection{Amsterdam}

The tourism strategy of Amsterdam aims at changing the image of the city by attracting a different mix of visitors and to get them to broaden their horizons by visiting more sites of interest, moving outwards from the immediate city centre. Therefore, they want to promote new aspects of the city's $\mathrm{CH}$, such as Amsterdam as cultural city or city of events. In addition, smaller attractions should also be integrated into Amsterdam's positioning strategy through the use of themes such as 2008's Hidden Treasures.

From the factor analysis of the Amsterdam tourists, three groups of tourists could be distinguished: $\mathrm{CH}$ enthusiasts, tangible $\mathrm{CH}$ fans and tourists that in particular like cultural events. The $\mathrm{CH}$ enthusiasts are generally younger persons, women, who already use ES to plan their trips. They are often international tourists. Tangible $\mathrm{CH}$ fans are often older international tourists, with a higher education. The cultural events fans are often younger persons, men, who do use ES and generally come from the Netherlands. From this, we can conclude that there are three main target groups of tourists in Amsterdam that could be reached by an online platform:

1. Older international tourists: older, higher educated international tourists are often interested in tangible $\mathrm{CH}$, they mostly appreciate conventional ES.

2. Younger international tourists: young, lower educated tourists that prefer intangible $\mathrm{CH}$ and who use in particular a journey planner, as well as an interactive map and an online booking system. In addition, they enjoy more often interactive games as well as an E-forum.

3. National tourists: a relatively large group of Dutch tourists is very interested in cultural events. For them a journey planner, as well as an interactive map and an online booking system is very useful. In addition, they also appreciate virtual tours. 
5.2 Leipzig

A main goal of the municipality of Leipzig, with respect to city marketing, is to attract more residents and German tourists to enjoy architecture and the urban landscape. However, from the three main groups of tourists that are interested in $\mathrm{CH}$, the first two (biggest) groups are mostly international tourists and only the third group consists of German tourists.

According to the factor analysis, the biggest group of tourists can be typified as $\mathrm{CH}$ enthusiast but without the clear intention to visit anything. Those persons are generally older, often women with a higher education. They visit Leipzig for pleasure and they use ES to prepare their leisure time. Furthermore, they are often international tourists. The second group can be described as tourists that plan to visit tangible $\mathrm{CH}$ attractions and that are not interested in intangible $\mathrm{CH}$. These tourists are also often older and higher educated persons, with higher income, but not necessarily women. They are relatively often from the Netherlands or form other countries outside Germany. The third group of tourists consists of tourists that like architecture as well as the urban landscape, what they also plan to visit. However, they are not so much interested in museums or cultural events and do not intend to visit them either. They often have a higher income and they do not use ES. They are mostly German.

From this, we can conclude that there are two main target groups of tourists in Leipzig that could be reached by an online platform:

1. The international tourists which are often older persons with a higher education. They are used to ES in relation to leisure and they favour all kinds of ES.

2. The national tourists that are in particular interested in architecture and urban landscape. However, this group is rather diverse and they are not all used to ES.

5.3 Genoa

The municipality of Genoa is in particular interested in attracting more Italian tourists. However, the biggest group of tourists that are interested in $\mathrm{CH}$ are often international tourists. Furthermore, Italian tourists seem to be less interested in (tangible) $\mathrm{CH}$.

For Genoa, we can distinguish three main groups of tourists as well. First of all, the general $\mathrm{CH}$ fans; as in Leipzig, those tourists like all kinds of $\mathrm{CH}$, only they haven't made any plans to visit anything yet. These international tourists are often men on business trips. They use ES and are often member of a $\mathrm{CH}$ association. The second group can be seen as those tourists that in particular favour tangible $\mathrm{CH}$. In contrast to the $\mathrm{CH}$ enthusiasts they have planned to visit some of those places. The tangible $\mathrm{CH}$ fans are often older persons, with a slightly lower education. The third group can be described as the group of tourists that do not really appreciate tangible $\mathrm{CH}$, instead they prefer intangible $\mathrm{CH}$. They are generally younger and mostly interested in conventional ES.

Although the municipality aims at attracting more Italian tourists, international tourists could perhaps more easily be attracted. We distinguish three target groups:

1. International tourists, which are often business persons and that already use ES to plan their trip ;

2. Younger tourists that prefer intangible $\mathrm{CH}$ and who can be attracted by conventional ES;

3. Older tourists that prefer tangible $\mathrm{CH}$. However, it can be difficult to reach such tourists with the ISAAC platform as they are less used to ES; 


\section{Final Conclusions}

Over the past 40 years, tourism has become a major activity in our society and an increasingly important sector in terms of economic development. It forms an increasing share of discretionary income and often provides new opportunities for upgrading the local environment. Important insights from the literature described in this contribution are that cultural heritage will increasingly become a tool to positively affect the destination image of a city. This is partly because of the growing competition in the tourism industry and the importance for a city to distinguish itself. At the same time, as the tourist population tends to become older, there will be a growing number of cultural heritage interested visitors. In order to spread tourists more equally over a city, ICT or e-services can be a useful tool to attract them to other, less well-known, interesting (cultural heritage) sights. In this study we performed ordered logit analyses and facto analyses to get more insight in what kind of tourists prefer $\mathrm{CH}$ objects and through which kind of ES they could be reached by the municipalities.

Although the tourist groups in the three cities are very different (e.g., more international tourists in Amsterdam and more national tourists in Leipzig and Genoa) in general, we can conclude that, in all three cities, there are three main target groups:

1. CH enthusiasts: (older) women, persons that do use ES, often with a higher education and often with a membership of a $\mathrm{CH}$ association. It is not really clear what the kinds of ES would be to reach this group: probably conventional ES, but perhaps also other kinds.

2. Intangible $\mathrm{CH}$ fans: younger persons that are interested in all kinds of ES

3. Tangible $\mathrm{CH}$ fans: older persons, often with a higher education. Those persons can best be reached by conventional ES.

Interestingly, in all three cities, the most important group of tourists, the $\mathrm{CH}$ enthusiasts, are often international tourists. This stresses the importance of multilingual ES in order to maximise its impact on $\mathrm{CH}$ visitors and the tourism sector. In addition, it is also important to note that certain ES become more important for tourists from further away. This is represented, for example, by their desire for an online booking system.

Even though the tourist groups are relatively different in the three cities, when focussing on the appreciation of $\mathrm{CH}$ we find less difference between tourists from different countries in appreciating specific ES. This suggests that online platforms could offer more or less the same ES in the three cities, however, the content of those ES i.e. the kind of $\mathrm{CH}$ elements that are emphasised, should be different.

Finally, an important finding is that the preferences for ES of persons interested in $\mathrm{CH}$ who did plan a visit, and the ones that did not plan, are very different. This insight is rather important: different ES can attract different users depending on whether they have already decided to visit a $\mathrm{CH}$ site or not. This means that it is important to have different areas at an online platform for persons that are still in the orientation phase of planning their visit and for persons with more knowledge about the city as well as for those that already visited it.

\section{References}

Ark, L.A. van der, and Richards G. (2006) 'Attractiveness of Cultural Activities in European Cities: a Latent Class Approach’, Tourism Management, Vol. 27, No. 6, pp. 1408-1413.

Boniface B. and Cooper C. (2001) 'Worldwide Destinations: The Geography of Travel and Tourism', Butterworth-Heinemann, Oxford 
Crompton, J. (1979) 'Motivations of pleasure vacations', Annals of Tourism Research, Vol. 6. No.4, pp.408-24.

Crompton, J. L. (1992) 'Structure of Vacation destination Choice Sets', Annals of Tourism Research Vol. 19, pp. 420-434.

European Travel Commission (2004) 'Tourism Trends for Europe'. Brussels, Belgium. www.etccorporate.org

Eyman A. and Ronning G. (1997) 'Microeconomic models of tourists' destination choice', Regional Science and Urban Economics, Vol. 27, pp.735-761.

Forte, F., Fusco Girard, L., and Nijkamp, P. (2006) 'Smart Policy, Creative Strategy and Urban Development', Studies in Regional Science, Vol. 35, No. 4, pp. 947-963.

Fusco Girard, L., and Nijkamp, P. (2009) 'Cultural Tourism and Sustainable Development' (eds.), Ashgate, Aldershot, UK.

Giaoutzi, M., and Nijkamp P. (eds.) (2006) 'Tourism and Regional Development', Ashgate, Aldershot.

Goeldner, C.R., and Ritchie B. (2006) 'Tourism: Principles, Practices, Philosophies', John Wiley, New York.

Greene, W. H., Hensher, D. A. (2008) 'Modeling ordered choices: A primer and recent developments', Leonard N. Stern School of Business, Department of Economics, Working Paper 08-26, New York.

Hsu, T., Tsai Y., and Wu H. (2009) 'The Preference Analysis for Tourist Choice of Destination: A Case Study of Taiwan’, Tourism Management, Vol. 30, No.2, pp. 288-297.

Kozak, M. (2002) 'Comparative Analysis of Tourist Motivations by Nationality and Destinations', Tourism Management, Vol. 23, pp. 221-232.

Lawson R. (1991) 'Patterns of tourist expenditure and types of vacation across the family life cycle', Journal of Travel Research, Vol. 29, No. 4, pp. 12-18.

Mathias, A., Nijkamp P. and Neto P. (eds.) (2007) 'Advances in Modern Tourism', Physica-Verlag, Heidelberg.

Mohsin A. (2005) 'Tourist attitudes and destination marketing - the case of Australia's Northern Territori and Malaysia'. Tourism Management, Vol. 26, pp. 723-732.

Nahab, S. (1975) 'Tourism Management', Tourism International Press, London.

Pearce, D. (1988) 'Tourism Time Budgets', Annuals of Tourism Research, Vol. 15, no.1, pp. 106-121.

Riganti, P., and Nijkamp P. (2008) 'Congestion in Popular Tourist Areas: A Multi-Attribute Experimental Choice Analysis of Willingness-to-Wait in Amsterdam', Tourism Economics, Vol. 14, no.1, pp. 25-44.

Spence, M. (2004) 'Efficiency and Personalization as Value Creation in Internationalizing HighTechnology SMEs', Canadian Journal of Administrative Sciences; ABI/INFORM Global, pp. 65-78.

Suh, K., and McAvoy L. (2005) 'Preferences and Trip Expenditures. A Conjoint Analysis of Visitors to Seoul, Korea', Tourism Management, Vol 26, pp. 325-333.

Uysal, M., and Hagan L. (1993) 'Motivations of Pleasure Travel and Tourism', Encyclopaedia of hospitality and tourism (M. Khan, M. Olsen and T. Var, eds.), Van Nostrand Reinhold, New York, pp. 798-810.

Van Leeuwen, E.S. and Nijkamp P. (2009) 'Operational Advances in Tourism Research'. Estudos Regionalis, Vol. 22, pp. 5-19.

Wall, G. \& Mathieson, A. (2006) 'Tourism: change, impacts and opportunities'. Book review. Journal of Vacation Marketing. Vol. 12, No. 3, pp. 292-293. 


\section{Appendix 1 Logit Models for Cultural Heritage}

Table A1: Coefficients of the ordered logit models estimating the preferences of tourists in Amsterdam for different types of $\mathrm{CH}$

\begin{tabular}{|c|c|c|c|c|c|c|c|c|}
\hline & Architecture & Monuments & Museums & $\begin{array}{l}\text { Urban } \\
\text { Landscape }\end{array}$ & $\begin{array}{l}\text { Cultural } \\
\text { events }\end{array}$ & Traditions & Customs & Knowledge \\
\hline E-service & $\begin{array}{l}0.205 \\
(0.160)\end{array}$ & $\begin{array}{l}0.319 * * \\
(0.152)\end{array}$ & $\begin{array}{l}0.581^{* * *} \\
(0.154)\end{array}$ & $\begin{array}{l}0.334^{* *} \\
(0.155)\end{array}$ & $\begin{array}{l}0.262 * \\
(0.151)\end{array}$ & $\begin{array}{l}0.257 * \\
(0.160)\end{array}$ & $\begin{array}{l}0.180 \\
(0.154)\end{array}$ & $\begin{array}{l}0.014 \\
(0.157)\end{array}$ \\
\hline Age & $\begin{array}{l}0.193^{*} \\
(0.113)\end{array}$ & $\begin{array}{l}0.392 * * * \\
(0.108)\end{array}$ & $\begin{array}{l}0.338 * * * \\
(0.106)\end{array}$ & $\begin{array}{l}0.213^{* *} \\
(0.101)\end{array}$ & $\begin{array}{l}-0.351 * * * \\
(0.107)\end{array}$ & $\begin{array}{l}-0.362 * * * \\
(0.119)\end{array}$ & $\begin{array}{l}-0.197 * \\
(0.120)\end{array}$ & $\begin{array}{l}0.062 \\
(0.115)\end{array}$ \\
\hline Education & $\begin{array}{l}0.229 * * * \\
(0.068)\end{array}$ & $\begin{array}{l}0.090 \\
(0.065)\end{array}$ & $\begin{array}{l}0.103 \\
(0.067)\end{array}$ & $\begin{array}{l}0.187 * * * \\
(0.063)\end{array}$ & $\begin{array}{l}-0.108^{*} \\
(0.059)\end{array}$ & $\begin{array}{l}-0.098^{*} \\
(0.059)\end{array}$ & $\begin{array}{l}-0.121^{* *} \\
0.056\end{array}$ & $\begin{array}{l}-0.132 * * \\
(0.059)\end{array}$ \\
\hline Gender & $\begin{array}{l}0.255^{*} \\
(0.147)\end{array}$ & $\begin{array}{l}0.269 * * \\
(0.141)\end{array}$ & $\begin{array}{l}0.310 * * \\
(0.146)\end{array}$ & $\begin{array}{l}0.528 * * * \\
(0.144)\end{array}$ & $\begin{array}{l}0.109 \\
(0.140)\end{array}$ & $\begin{array}{l}0.481^{* * *} \\
(0.143)\end{array}$ & $\begin{array}{l}0.380^{* * *} \\
0.141\end{array}$ & $\begin{array}{l}0.248 * \\
(0.143)\end{array}$ \\
\hline USA & $\begin{array}{l}0.233 \\
(0.221)\end{array}$ & $\begin{array}{l}0.254 \\
(0.217)\end{array}$ & $\begin{array}{l}-0.076 \\
(0.217)\end{array}$ & $\begin{array}{l}-0.039 \\
(0.214)\end{array}$ & $\begin{array}{l}-0.747 * * * \\
(0.224)\end{array}$ & $\begin{array}{l}1.790 * * * \\
(0.252)\end{array}$ & $\begin{array}{l}1.503^{* * *} \\
0.240\end{array}$ & $\begin{array}{l}1.199 * * * \\
(0.245)\end{array}$ \\
\hline UK & $\begin{array}{l}0.210 \\
(0.228)\end{array}$ & $\begin{array}{l}-0.004 \\
(0.247)\end{array}$ & $\begin{array}{l}-0.271 \\
(0.253)\end{array}$ & $\begin{array}{l}-0.260 \\
(0.234)\end{array}$ & $\begin{array}{l}-0.785 * * * \\
(0.254)\end{array}$ & $\begin{array}{l}1.915^{* * *} \\
(0.244)\end{array}$ & $\begin{array}{l}1.518^{* * *} \\
0.255\end{array}$ & $\begin{array}{l}1.588^{* * *} \\
(0.271)\end{array}$ \\
\hline Germany & $\begin{array}{l}0.554^{* *} \\
(0.252)\end{array}$ & $\begin{array}{l}-0.494^{* *} \\
(0.255)\end{array}$ & $\begin{array}{l}-0.030 \\
(0.249)\end{array}$ & $\begin{array}{l}-0.308 \\
(0.251)\end{array}$ & $\begin{array}{l}-1.338^{* * *} \\
(0.249)\end{array}$ & $\begin{array}{l}0.568 * * * \\
(0.222)\end{array}$ & $\begin{array}{l}0.227 \\
0.228\end{array}$ & $\begin{array}{l}0.270 \\
(0.227)\end{array}$ \\
\hline $\begin{array}{l}\text { Rest } \\
\text { Europe }\end{array}$ & $\begin{array}{l}0.492 * * \\
(0.219)\end{array}$ & $\begin{array}{l}-0.298 \\
(0.223)\end{array}$ & $\begin{array}{l}-0.218 \\
(0.222)\end{array}$ & $\begin{array}{l}-0.160 \\
(0.225)\end{array}$ & $\begin{array}{l}-0.796 * * * \\
(0.224)\end{array}$ & $\begin{array}{l}1.237 * * * \\
(0.234)\end{array}$ & $\begin{array}{l}1.189 * * * \\
(0.225)\end{array}$ & $\begin{array}{l}1.032^{* * *} \\
(0.212)\end{array}$ \\
\hline Rest world & $\begin{array}{l}0.305 \\
(0.323)\end{array}$ & $\begin{array}{l}-0.075 \\
(0.304)\end{array}$ & $\begin{array}{l}0.390 \\
(0.291)\end{array}$ & $\begin{array}{l}-0.224 \\
(0.307)\end{array}$ & $\begin{array}{l}-0.775 * * * \\
(0.286)\end{array}$ & $\begin{array}{l}1.597 * * * \\
(0.323)\end{array}$ & $\begin{array}{l}1.301^{* * *} \\
(0.283)\end{array}$ & $\begin{array}{l}0.951^{* * *} \\
(0.294)\end{array}$ \\
\hline Observations & 371 & 364 & 361 & 372 & 363 & 367 & 353 & 357 \\
\hline $\begin{array}{l}\text { Log } \\
\text { Likelihood }\end{array}$ & -369.561 & -490.917 & -488.302 & -400.622 & -495.341 & -522.924 & -521.219 & -515.910 \\
\hline $\begin{array}{l}\text { McFadden } \\
\text { pseudo- } R^{2}\end{array}$ & 0.032 & 0.015 & 0.012 & 0.010 & 0.029 & 0.018 & 0.009 & 0.013 \\
\hline
\end{tabular}

Table A2: Coefficients of the ordered logit models estimating the preferences of tourists in Leipzig for different types of $\mathrm{CH}$

\begin{tabular}{l|llllllll}
\hline & Architecture & Monuments & Museums & $\begin{array}{l}\text { Urban } \\
\text { Landscape }\end{array}$ & $\begin{array}{l}\text { Cultural } \\
\text { events }\end{array}$ & Traditions & Customs & Knowledge \\
\hline \multirow{2}{*}{ E-service } & 0.086 & 0.183 & 0.057 & 0.153 & 0.341 & $0.484^{* *}$ & $0.366^{*}$ & $0.367^{*}$ \\
& $(0.207)$ & $(0.205)$ & $(0.214)$ & $(0.202)$ & $(0.213)$ & $(0.197)$ & $(0.215)$ & $(0.214)$ \\
Age & -0.139 & $0.334^{* *}$ & -0.016 & -0.087 & -0.253 & -0.217 & -0.061 & -0.189 \\
& $(0.165)$ & $(0.139)$ & $(0.154)$ & $(0.153)$ & $(0.170)$ & $(0.178)$ & $(0.179)$ & $(0.154)$ \\
Employed & $-0.778^{* * *}$ & 0.225 & $-0.438^{* *}$ & -0.107 & $-0.941^{* * *}$ & 0.208 & 0.099 & 0.270 \\
& $(0.234)$ & $(0.216)$ & $(0.222)$ & $(0.217)$ & $(0.216)$ & $(0.235)$ & $(0.212)$ & $(0.220)$ \\
Education & $0.233^{* * *}$ & 0.089 & $0.203^{* *}$ & 0.021 & $0.165^{*}$ & $-0.191^{* *}$ & -0.110 & -0.102 \\
& $(0.084)$ & $(0.077)$ & $(0.081)$ & $(0.091)$ & $(0.089)$ & $(0.085)$ & $(0.094)$ & $(0.079)$ \\
Income & 0.132 & $-0.138^{* *}$ & 0.043 & 0.111 & 0.049 & 0.017 & -0.020 & -0.017 \\
& $(0.088)$ & $(0.070)$ & $(0.075)$ & $(0.085)$ & $(0.074)$ & $(0.080)$ & $(0.086)$ & $(0.072)$ \\
Gender & 0.023 & $-0.464 * *$ & 0.017 & 0.189 & $0.384^{*}$ & 0.068 & 0.131 & 0.031 \\
& $(0.206)$ & $(0.199)$ & $(0.197)$ & $(0.202)$ & $(0.205)$ & $(0.196)$ & $(0.208)$ & $(0.201)$ \\
\hline
\end{tabular}




\begin{tabular}{|c|c|c|c|c|c|c|c|c|}
\hline Rest World & $\begin{array}{l}-1.063 \\
(0.674)\end{array}$ & $\begin{array}{l}0.131 \\
(0.469)\end{array}$ & - & $\begin{array}{l}-1.005^{*} \\
(0.622)\end{array}$ & $\begin{array}{l}-0.665 \\
(0.526)\end{array}$ & $\begin{array}{l}1.095 \\
(0.744)\end{array}$ & $\begin{array}{l}0.881 \\
(0.560)\end{array}$ & $\begin{array}{l}0.553 \\
(0.614)\end{array}$ \\
\hline $\begin{array}{l}\text { Rest } \\
\text { Europe }\end{array}$ & $\begin{array}{l}0.152 \\
(0.341)\end{array}$ & $\begin{array}{l}0.480 \\
(0.383)\end{array}$ & - & $\begin{array}{l}-0.497 \\
(0.338)\end{array}$ & $\begin{array}{l}-0.509 * \\
(0.296)\end{array}$ & $\begin{array}{l}0.373 \\
(0.300)\end{array}$ & $\begin{array}{l}0.164 \\
(0.352)\end{array}$ & $\begin{array}{l}-0.339 \\
(0.344)\end{array}$ \\
\hline $\begin{array}{l}\text { Observatio } \\
\text { ns }\end{array}$ & 371 & 364 & 361 & 372 & 363 & 367 & 353 & 357 \\
\hline $\begin{array}{l}\text { Log } \\
\text { Likelihood }\end{array}$ & -369.561 & -490.917 & -488.302 & -400.622 & -495.341 & -522.924 & -521.219 & -515.910 \\
\hline $\begin{array}{l}\text { McFadden } \\
\text { pseudo- } R^{2}\end{array}$ & 0.032 & 0.015 & 0.012 & 0.010 & 0.029 & 0.018 & 0.009 & 0.013 \\
\hline
\end{tabular}

Table A3: Coefficients of the ordered logit models estimating the preferences of tourists in Genoa for different types of $\mathrm{CH}$

\begin{tabular}{|c|c|c|c|c|c|c|c|c|}
\hline & Architecture & Monuments & Museums & $\begin{array}{l}\text { Urban } \\
\text { Landscape }\end{array}$ & $\begin{array}{l}\text { Cultural } \\
\text { events }\end{array}$ & Traditions & Customs & Knowledge \\
\hline E-service & $\begin{array}{l}0.210 \\
(0.206)\end{array}$ & $\begin{array}{l}0.188 \\
(0.179)\end{array}$ & $\begin{array}{l}0.409 * * \\
(0.198)\end{array}$ & $\begin{array}{l}0.165 \\
(0.223)\end{array}$ & $\begin{array}{l}0.176 \\
(0.170)\end{array}$ & $\begin{array}{l}0.336 * \\
(0.197)\end{array}$ & $\begin{array}{l}-0.020 \\
(0.195)\end{array}$ & $\begin{array}{l}-0.031 \\
(0.186)\end{array}$ \\
\hline Age & $\begin{array}{l}0.160 \\
(0.133)\end{array}$ & $\begin{array}{l}0.150 \\
(0.118)\end{array}$ & $\begin{array}{l}0.013 \\
(0.126)\end{array}$ & $\begin{array}{l}0.138 \\
(0.130)\end{array}$ & $\begin{array}{l}-0.030 \\
(0.129)\end{array}$ & $\begin{array}{l}-0.048 \\
(0.130)\end{array}$ & $\begin{array}{l}-0.181 \\
(0.118)\end{array}$ & $\begin{array}{l}-0.159 \\
(0.123)\end{array}$ \\
\hline Employed & $\begin{array}{l}0.236 \\
(0.180)\end{array}$ & $\begin{array}{l}0.217 \\
(0.172)\end{array}$ & $\begin{array}{l}-0.095 \\
(0.176)\end{array}$ & $\begin{array}{l}0.059 \\
(0.169)\end{array}$ & $\begin{array}{l}0.025 \\
(0.177)\end{array}$ & $\begin{array}{l}0.073 \\
(0.175)\end{array}$ & $\begin{array}{l}-0.080 \\
(0.172)\end{array}$ & $\begin{array}{l}0.177 \\
(0.173)\end{array}$ \\
\hline Education & $\begin{array}{l}0.014 \\
(0.068)\end{array}$ & $\begin{array}{l}-0.171^{* * *} \\
(0.063)\end{array}$ & $\begin{array}{l}-0.008 \\
(0.065)\end{array}$ & $\begin{array}{l}0.021 \\
(0.065)\end{array}$ & $\begin{array}{l}-0.015 \\
(0.062)\end{array}$ & $\begin{array}{l}-0.017 \\
(0.066)\end{array}$ & $\begin{array}{l}0.064 \\
(0.066)\end{array}$ & $\begin{array}{l}0.042 \\
(0.065)\end{array}$ \\
\hline Gender & $\begin{array}{l}0.260 * \\
(0.158)\end{array}$ & $\begin{array}{l}0.142 \\
(0.153)\end{array}$ & $\begin{array}{l}0.401^{* * *} \\
(0.157)\end{array}$ & $\begin{array}{l}0.129 \\
(0.149)\end{array}$ & $\begin{array}{l}-0.090 \\
(0.150)\end{array}$ & $\begin{array}{l}0.099 \\
(0.149)\end{array}$ & $\begin{array}{l}0.347^{* *} \\
(0.149)\end{array}$ & $\begin{array}{l}0.238 \\
(0.149)\end{array}$ \\
\hline Italy & $\begin{array}{l}-0.349 \\
(0.249)\end{array}$ & $\begin{array}{l}-0.428 * \\
(0.237)\end{array}$ & $\begin{array}{l}-0.075 \\
(0.255)\end{array}$ & $\begin{array}{l}-0.192 \\
0.252\end{array}$ & $\begin{array}{l}-0.274 \\
(0.232)\end{array}$ & $\begin{array}{l}-0.309 \\
(0.211)\end{array}$ & $\begin{array}{l}0.081 \\
(0.243)\end{array}$ & $\begin{array}{l}-0.010 \\
(0.247)\end{array}$ \\
\hline Observations & 620 & 620 & 613 & 620 & 621 & 621 & 621 & 621 \\
\hline $\begin{array}{l}\text { Log } \\
\text { Likelihood }\end{array}$ & -706.656 & -786.0634 & -768.325 & -816.015 & -807.598 & -843.079 & -865.505 & -877.873 \\
\hline $\begin{array}{l}\text { McFadden } \\
\text { pseudo- } R^{2}\end{array}$ & 0.008 & 0.011 & 0.008 & 0.003 & 0.002 & 0.004 & 0.006 & 0.003 \\
\hline
\end{tabular}

Significant at ${ }^{* * *} 0.01, * * 0.05$ and $* 0.10$ levels.

\section{Appendix 2 Logit Models for E-services}

Table A4: Coefficients of the ordered logit models estimating the preferences of tourists in Amsterdam for different types of ES

\begin{tabular}{l|ccccccc}
\hline & $\begin{array}{c}\text { Interactive } \\
\text { map }\end{array}$ & $\begin{array}{c}\text { Personalised } \\
\text { information }\end{array}$ & $\begin{array}{c}\text { Booking } \\
\text { service }\end{array}$ & $\begin{array}{c}\text { Journey } \\
\text { planner }\end{array}$ & e-Forum & $\begin{array}{c}\text { Virtual } \\
\text { Tours }\end{array}$ & $\begin{array}{c}\text { Interactive } \\
\text { games }\end{array}$ \\
\hline E-service & $0.497 * * *$ & $0.343^{* *}$ & $1.156 * * *$ & $0.373^{* *}$ & $0.362^{* *}$ & 0.193 & 0.091 \\
& $(0.156)$ & $(0.153)$ & $(0.164)$ & $(0.157)$ & $(0.147)$ & $(0.152)$ & $(0.168)$ \\
Education & 0.074 & $-0.205^{* * *}$ & 0.055 & 0.026 & $-0.210^{* * *}$ & $-0.124^{*}$ & $-0.339^{* * *}$ \\
& $(0.062)$ & $(0.065)$ & $(0.065)$ & $(0.059)$ & $(0.063)$ & $(0.065)$ & $(0.070)$ \\
Gender & 0.082 & -0.070 & -0.065 & 0.158 & -0.094 & $-0.294^{* *}$ & $-0.423^{* * *}$ \\
& $(0.147)$ & $(0.145)$ & $(0.148)$ & $(0.144)$ & $(0.142)$ & $(0.143)$ & $(0.161)$ \\
Age & $-0.189 *$ & -0.182 & $-0.248^{* *}$ & -0.103 & $-0.470 * * *$ & 0.011 & $-0.434^{* * *}$ \\
& $(0.114)$ & $(0.117)$ & $(0.116)$ & $(0.107)$ & $(0.107)$ & $(0.114)$ & $(0.123)$ \\
\hline
\end{tabular}




\begin{tabular}{|c|c|c|c|c|c|c|c|}
\hline Employed & $\begin{array}{c}0.317^{* *} \\
(0.160)\end{array}$ & $\begin{array}{l}-0.026 \\
(0.163)\end{array}$ & $\begin{array}{c}0.098 \\
(0.157)\end{array}$ & $\begin{array}{c}0.167 \\
(0.152)\end{array}$ & $\begin{array}{c}0.177 \\
(0.152)\end{array}$ & $\begin{array}{c}0.186 \\
(0.152)\end{array}$ & $\begin{array}{c}-0.054 \\
(0.178)\end{array}$ \\
\hline USA & $\begin{array}{c}0.814^{* * *} \\
(0.217)\end{array}$ & $\begin{array}{c}0.706 * * * \\
(0.235)\end{array}$ & $\begin{array}{c}0.755^{* * *} \\
(0.241)\end{array}$ & $\begin{array}{c}-0.294 \\
(0.214)\end{array}$ & $\begin{array}{c}0.261 \\
(0.215)\end{array}$ & $\begin{array}{c}0.341 \\
(0.228)\end{array}$ & $\begin{array}{l}-0.171 \\
(0.252)\end{array}$ \\
\hline UK & $\begin{array}{c}0.594 * * \\
(0.245)\end{array}$ & $\begin{array}{c}0.601^{* *} \\
(0.262)\end{array}$ & $\begin{array}{c}0.680 * * * \\
(0.234)\end{array}$ & $\begin{array}{c}0.368 \\
(0.244)\end{array}$ & $\begin{array}{c}0.254 \\
(0.251)\end{array}$ & $\begin{array}{l}0.458 * \\
(0.235)\end{array}$ & $\begin{array}{c}0.675 * * * \\
(0.259)\end{array}$ \\
\hline Germany & $\begin{array}{c}0.328 \\
(0.233)\end{array}$ & $\begin{array}{c}0.247 \\
(0.234)\end{array}$ & $\begin{array}{l}-0.047 \\
(0.243)\end{array}$ & $\begin{array}{c}-0.808 * * * \\
(0.232)\end{array}$ & $\begin{array}{l}-0.070 \\
(0.232)\end{array}$ & $\begin{array}{c}0.052 \\
(0.231)\end{array}$ & $\begin{array}{c}0.131 \\
(0.273)\end{array}$ \\
\hline $\begin{array}{l}\text { Rest of } \\
\text { Europe }\end{array}$ & $\begin{array}{c}0.894 * * * \\
(0.217)\end{array}$ & $\begin{array}{c}0.792 * * * \\
(0.225)\end{array}$ & $\begin{array}{c}0.593 * * * \\
(0.221)\end{array}$ & $\begin{array}{c}-0.500 * * \\
(0.219)\end{array}$ & $\begin{array}{c}0.460 * * \\
(0.230)\end{array}$ & $\begin{array}{l}0.396 * \\
(0.214)\end{array}$ & $\begin{array}{c}0.286 \\
(0.248)\end{array}$ \\
\hline $\begin{array}{l}\text { Rest of the } \\
\text { world }\end{array}$ & $\begin{array}{c}0.823^{* *} \\
(0.331)\end{array}$ & $\begin{array}{c}1.021^{* * * *} \\
(0.278)\end{array}$ & $\begin{array}{c}1.315^{* * * *} \\
(0.291)\end{array}$ & $\begin{array}{l}-0.471 \\
(0.303)\end{array}$ & $\begin{array}{c}0.735^{* * *} \\
(0.260)\end{array}$ & $\begin{array}{c}0.283 \\
(0.272)\end{array}$ & $\begin{array}{c}0.351 \\
(0.315)\end{array}$ \\
\hline Observations & 650 & 651 & 651 & 651 & 651 & 651 & 650 \\
\hline $\begin{array}{l}\text { Log } \\
\text { Likelihood }\end{array}$ & -930.711 & -979.054 & -905.722 & -986.545 & -959.905 & -1010.997 & -759.831 \\
\hline $\begin{array}{l}\text { McFadden } \\
\text { pseudo- } R^{2}\end{array}$ & 0.026 & 0.022 & 0.055 & 0.018 & 0.027 & 0.010 & 0.047 \\
\hline
\end{tabular}

Table A5: Coefficients of the ordered logit models estimating the preferences of tourists in Leipzig for different types of ES

\begin{tabular}{|c|c|c|c|c|c|c|c|}
\hline & $\begin{array}{c}\text { Interactive } \\
\text { map }\end{array}$ & $\begin{array}{l}\text { Personalised } \\
\text { information }\end{array}$ & $\begin{array}{l}\text { Booking } \\
\text { service }\end{array}$ & $\begin{array}{l}\text { Journey } \\
\text { planner }\end{array}$ & e-Forum & $\begin{array}{l}\text { Virtual } \\
\text { Tours }\end{array}$ & $\begin{array}{l}\text { Interactive } \\
\text { games }^{1}\end{array}$ \\
\hline E-service & $\begin{array}{c}0.489 * * * \\
(0.156)\end{array}$ & $\begin{array}{c}0.422^{* * * *} \\
(0.159)\end{array}$ & $\begin{array}{c}1.034^{* * *} \\
(0.163)\end{array}$ & $\begin{array}{c}0.737 * * * \\
(0.160)\end{array}$ & $\begin{array}{c}0.560 * * * \\
(0.166)\end{array}$ & $\begin{array}{c}0.445^{* * * *} \\
(0.158)\end{array}$ & $\begin{array}{l}-0.153 \\
(0.177)\end{array}$ \\
\hline Education & $\begin{array}{c}-0.031 \\
(0.064)\end{array}$ & $\begin{array}{c}0.039 \\
(0.062)\end{array}$ & $\begin{array}{c}0.090 \\
(0.065)\end{array}$ & $\begin{array}{l}-0.063 \\
(0.065)\end{array}$ & $\begin{array}{c}-0.225^{* * *} \\
(0.063)\end{array}$ & $\begin{array}{c}-0.126^{* *} \\
(0.063)\end{array}$ & $\begin{array}{c}-0.127 * * \\
(0.066)\end{array}$ \\
\hline Gender & $\begin{array}{c}0.015 \\
(0.157)\end{array}$ & $\begin{array}{c}0.027 \\
(0.158)\end{array}$ & $\begin{array}{c}0.178 \\
(0.156)\end{array}$ & $\begin{array}{l}-0.062 \\
(0.155)\end{array}$ & $\begin{array}{c}0.131 \\
(0.156)\end{array}$ & $\begin{array}{c}-0.031 \\
(0.158)\end{array}$ & $\begin{array}{l}-0.041 \\
(0.177)\end{array}$ \\
\hline Age & $\begin{array}{c}-0.004 \\
(0.096)\end{array}$ & $\begin{array}{c}0.044 \\
(0.101)\end{array}$ & $\begin{array}{c}0.065 \\
(0.100)\end{array}$ & $\begin{array}{c}0.068 \\
(0.104)\end{array}$ & $\begin{array}{c}-0.009 \\
(0.101)\end{array}$ & $\begin{array}{c}0.098 \\
(0.103)\end{array}$ & $\begin{array}{c}-0.359 * * * \\
(0.117)\end{array}$ \\
\hline Employed & $\begin{array}{c}0.003 \\
(0.166)\end{array}$ & $\begin{array}{c}-0.237 \\
(0.162)\end{array}$ & $\begin{array}{c}0.117 \\
(0.174)\end{array}$ & $\begin{array}{l}-0.166 \\
(0.174)\end{array}$ & $\begin{array}{c}-0.061 \\
(0.166)\end{array}$ & $\begin{array}{c}0.057 \\
(0.161)\end{array}$ & $\begin{array}{l}-0.288 \\
(0.188)\end{array}$ \\
\hline Holland & $\begin{array}{l}-0.462 \\
(0.432)\end{array}$ & $\begin{array}{l}-0.533 \\
(0.395)\end{array}$ & $\begin{array}{l}-1.059 * \\
(0.644)\end{array}$ & $\begin{array}{c}-1.040^{* *} \\
(0.426)\end{array}$ & $\begin{array}{l}-0.293 \\
(0.512)\end{array}$ & $\begin{array}{c}0.109 \\
(0.449)\end{array}$ & - \\
\hline UK & $\begin{array}{c}-0.711 \\
(0.654)\end{array}$ & $\begin{array}{l}-0.363 \\
(0.508)\end{array}$ & $\begin{array}{l}-0.119 \\
(0.611)\end{array}$ & $\begin{array}{l}-0.482 \\
(1.030)\end{array}$ & $\begin{array}{l}-0.470 \\
(0.712)\end{array}$ & $\begin{array}{c}-0.883^{* *} \\
(0.395)\end{array}$ & - \\
\hline USA & $\begin{array}{c}0.129 \\
(0.278)\end{array}$ & $\begin{array}{c}0.757 * * * \\
(0.272)\end{array}$ & $\begin{array}{l}-0.004 \\
(0.635)\end{array}$ & $\begin{array}{c}0.131 \\
(0.486)\end{array}$ & $\begin{array}{l}-0.110 \\
(0.311)\end{array}$ & $\begin{array}{c}0.175 \\
(0.581)\end{array}$ & - \\
\hline Rest Europe & $\begin{array}{c}0.326 \\
(0.311)\end{array}$ & $\begin{array}{c}0.576 \\
(0.353)\end{array}$ & $\begin{array}{c}0.637 * * \\
(0.274)\end{array}$ & $\begin{array}{l}-0.093 \\
(0.255)\end{array}$ & $\begin{array}{c}0.318 \\
(0.315)\end{array}$ & $\begin{array}{l}-0.013 \\
(0.321)\end{array}$ & - \\
\hline Rest World & $\begin{array}{c}1.295 \\
(0.559)\end{array}$ & $\begin{array}{c}1.708^{* * * *} \\
(0.463)\end{array}$ & $\begin{array}{l}0.994^{*} \\
(0.521)\end{array}$ & $\begin{array}{c}0.738 \\
(0.578)\end{array}$ & $\begin{array}{c}0.275 \\
(0.362)\end{array}$ & $\begin{array}{c}0.046 \\
(0.425)\end{array}$ & - \\
\hline Observations & 569 & 538 & 559 & 560 & 552 & 549 & 533 \\
\hline $\begin{array}{l}\text { Log } \\
\text { Likelihood }\end{array}$ & -856.323 & -795.923 & -806.000 & -825.312 & -834.869 & -852.653 & -593.014 \\
\hline $\begin{array}{l}\text { McFadden } \\
\text { pseudo- } R^{2}\end{array}$ & 0.012 & 0.017 & 0.040 & 0.021 & 0.019 & 0.010 & 0.021 \\
\hline
\end{tabular}


Table A6: Coefficients of the ordered logit models estimating the preferences of tourists in Genoa for different types of ES

\begin{tabular}{|c|c|c|c|c|c|c|c|}
\hline & $\begin{array}{c}\text { Interactive } \\
\text { map }\end{array}$ & $\begin{array}{l}\text { Personalised } \\
\text { information }\end{array}$ & $\begin{array}{l}\text { Booking } \\
\text { service }\end{array}$ & $\begin{array}{l}\text { Journey } \\
\text { planner }\end{array}$ & e-Forum & $\begin{array}{l}\text { Virtual } \\
\text { Tours }\end{array}$ & $\begin{array}{c}\text { Interactive } \\
\text { games }\end{array}$ \\
\hline E-service & $\begin{array}{c}0.024 \\
(0.223)\end{array}$ & $\begin{array}{l}-0.123 \\
(0.187)\end{array}$ & $\begin{array}{c}0.170 \\
(0.193)\end{array}$ & $\begin{array}{c}-0.507 * * \\
(0.225)\end{array}$ & $\begin{array}{c}0.189 \\
(0.198)\end{array}$ & $\begin{array}{l}0.356^{*} \\
(0.199)\end{array}$ & $\begin{array}{c}0.139 \\
(0.218)\end{array}$ \\
\hline Education & $\begin{array}{c}0.029 \\
(0.068)\end{array}$ & $\begin{array}{l}0.105 * \\
(0.063)\end{array}$ & $\begin{array}{c}0.138 * * \\
(0.067)\end{array}$ & $\begin{array}{l}-0.002 \\
(0.070)\end{array}$ & $\begin{array}{l}-0.035 \\
(0.059)\end{array}$ & $\begin{array}{l}-0.070 \\
(0.061)\end{array}$ & $\begin{array}{l}-0.109 * \\
(0.066)\end{array}$ \\
\hline Gender & $\begin{array}{l}-0.037 \\
(0.147)\end{array}$ & $\begin{array}{c}0.153 \\
(0.150)\end{array}$ & $\begin{array}{c}0.103 \\
(0.151)\end{array}$ & $\begin{array}{l}0.302 * \\
(0.164)\end{array}$ & $\begin{array}{l}-0.057 \\
(0.149)\end{array}$ & $\begin{array}{c}0.168 \\
(0.151)\end{array}$ & $\begin{array}{l}-0.109 \\
(0.155)\end{array}$ \\
\hline Age & $\begin{array}{c}0.040 \\
(0.136)\end{array}$ & $\begin{array}{c}0.167 \\
(0.131)\end{array}$ & $\begin{array}{c}0.077 \\
(0.128)\end{array}$ & $\begin{array}{c}0.011 \\
(0.131)\end{array}$ & $\begin{array}{c}-0.051 \\
(0.116)\end{array}$ & $\begin{array}{c}0.100 \\
(0.131)\end{array}$ & $\begin{array}{c}-0.432 * * * \\
(0.123)\end{array}$ \\
\hline Employed & $\begin{array}{c}-0.224 \\
(0.177)\end{array}$ & $\begin{array}{l}-0.078 \\
(0.176)\end{array}$ & $\begin{array}{l}-0.269 \\
(0.171)\end{array}$ & $\begin{array}{l}-0.325^{*} \\
(0.190)\end{array}$ & $\begin{array}{l}-0.219 \\
(0.165)\end{array}$ & $\begin{array}{l}-0.209 \\
(0.174)\end{array}$ & $\begin{array}{c}-0.041 \\
(0.172)\end{array}$ \\
\hline France & $\begin{array}{l}-0.048 \\
(0.390)\end{array}$ & $\begin{array}{c}0.089 \\
(0.407)\end{array}$ & $\begin{array}{l}-0.112 \\
(0.474)\end{array}$ & $\begin{array}{c}0.334 \\
(0.582)\end{array}$ & $\begin{array}{l}-0.463 \\
(0.344)\end{array}$ & $\begin{array}{c}0.308 \\
(0.518)\end{array}$ & $\begin{array}{c}0.123 \\
(0.402)\end{array}$ \\
\hline Spain & $\begin{array}{c}-0.751 * \\
(0.419)\end{array}$ & $\begin{array}{c}1.193^{* *} \\
(0.556)\end{array}$ & $\begin{array}{l}-0.050 \\
(0.531)\end{array}$ & $\begin{array}{c}0.040 \\
(0.395)\end{array}$ & $\begin{array}{c}0.436 \\
(0.356)\end{array}$ & $\begin{array}{c}-0.279 \\
(0.569)\end{array}$ & $\begin{array}{c}-0.428 \\
(0.577)\end{array}$ \\
\hline $\begin{array}{l}\text { Rest of } \\
\text { Europe }\end{array}$ & $\begin{array}{c}0.490 \\
(0.304)\end{array}$ & $\begin{array}{l}0.482 * \\
(0.293)\end{array}$ & $\begin{array}{l}-0.097 \\
(0.295)\end{array}$ & $\begin{array}{c}0.220 \\
(0.359)\end{array}$ & $\begin{array}{l}-0.307 \\
(0.354)\end{array}$ & $\begin{array}{l}-0.069 \\
(0.293)\end{array}$ & $\begin{array}{l}-0.025 \\
(0.273)\end{array}$ \\
\hline $\begin{array}{l}\text { Rest of the } \\
\text { world }\end{array}$ & $\begin{array}{l}-0.695 \\
(0.863)\end{array}$ & $\begin{array}{l}-0.163 \\
(0.616)\end{array}$ & $\begin{array}{c}-1.231^{* *} \\
(0.573)\end{array}$ & $\begin{array}{l}-0.145 \\
(0.585)\end{array}$ & $\begin{array}{c}0.006 \\
(0.571) \\
\end{array}$ & $\begin{array}{c}-0.441 \\
(0.397)\end{array}$ & $\begin{array}{c}0.073 \\
(0.530) \\
\end{array}$ \\
\hline Observations & 621 & 621 & 621 & 621 & 621 & 621 & 621 \\
\hline $\begin{array}{l}\text { Log } \\
\text { Likelihood }\end{array}$ & -859.919 & -854.082 & -811.003 & -691.889 & -949.308 & -943.559 & -800.399 \\
\hline $\begin{array}{l}\text { McFadden } \\
\text { pseudo- } R^{2}\end{array}$ & 0.005 & 0.009 & 0.007 & 0.009 & 0.004 & 0.004 & 0.011 \\
\hline
\end{tabular}

